\title{
Pengaruh Sistem Informasi Akuntansi dan Pelaporan Keuangan terhadap Pengendalian Manajemen pada Perusahaan Jasa Konstruksi (PT. X) di Jakarta
}

\author{
Edison Hamid \\ Stie Tribuana Tambun
}

\begin{abstract}
Accounting information system in charge of providing the information needed to facilitate monitoring and assessment of control measures against the management. There are five main functions of the accounting information system of data collection, data processing, data management, control data (including security), and producer information. This study aims to examine the effect of accounting information systems and financial reporting to management control. The results are expected to provide benefits in explaining and predicting the effects of accounting information systems and financial reporting to management control. This form of survey research studies that used questionnaires to collect data that need. To provide an overview of the demographics of respondents, the research data were analyzed with descriptive statistics. The quality of data generated from the use of research instruments was evaluated by rehabilitation and validity testing. The hypothesis was tested by multiple regression analysts to determine its influence on management control. The results with the conclusion that the accounting information system significantly influence the management control, financial reporting significant influence on management control, and test results together financial reporting was only significantly affected majanemen control, whereas no effect of accounting information systems are significant.
\end{abstract}

Keywords: Accounting Information Systems, Financial Reporting, Management Control.

\begin{abstract}
Abstrak Sistem Informasi akuntansi bertugas memberikan informasi yang dibutuhkan untuk memudahkan pengawasan dan tindakan terhadap penilaian pengendalian manajemen. Terdapat lima fungsi utama sistem informasi akuntansi yaitu pengumpulan data, pemerosesan data, manajemen data, pengendalian data (termasuk security), dan penghasil informasi. Penelitian ini bertujuan menguji pengaruh sistem informasi akuntansi dan pelaporan keuangan terhadap pengendalian manajemen. Hasil penelitian ini diharapkan dapat memberi manfaat dalam menjelaskan dan memprediksi tentang pengaruh sistem informasi akuntansi dan pelaporan keuangan terhadap pengendalian manajemen. Penelitian ini berbentuk survey research yang menggunakan instrumen kuesioner untuk mengumpulkan data yang di perlukan. Untuk memberikan gambaran mengenai demografi responden, data penelitian dianalisis dengan statistik deskriptif. Kualitas data yang dihasilkan dari penggunaan instrumen penelitian dievaluasi dengan uji reabilitas dan validitas. Hipotesis diuji dengan analis multiple regression untuk mengatahui pengaruhnya terhadap pengendalian manajemen. Hasil penelitian dengan kesimpulan bahwa sistem informasi akuntansi berpengaruh secara signifikan terhadap pengendalian manajemen, pelaporan keuangan berpengaruh secara signifikan terhadap pengendalian manajemen, dan hasil uji secara bersama-sama ternyata hanya pelaporan keuangan yang berpengaruh secara signifikan terhadap pengendalian manajemen, sedangkan sistem informasi akuntansi tidak berpengaruh secara signifikan.
\end{abstract}

Kata kunci: Sistem Informasi Akuntansi, Pelaporan Keuangan, Pengendalian Manajemen

\section{A. PENDAHULUAN}

Perusahaan adalah merupakan

suatu bentuk organisasi, dimana sekelompok orang secara bersamasama untuk melakukan kegiatan dengan tujuan tertentu. Pada umumnya organisasi perusahaan berorientasi kepada mencari keuntungan untuk menghidupi atau memenuhi kebutuhan kelompok tersebut atau masyarakat.
Pengembangan perusahaan menjadi lebih besar disamping tujuan agar usaha yang dilakukan dapat berhasil dengan baik, diperlukan adanya manajemen yang baik dan dapat bekerja secara efisien, efektif dan ekonomis dibantu sistem informasi akuntansi yang memadai sehingga dapat memperlancar dan memudahkan setiap tindakan serta dapat melakukan pengawasan dan pengendalian 
terhadap manajemen perusahaan.

Pengendalian manajemen yang baik bagi suatu perusahaan belum tentu baik pula bagi perusahaan lain, mengingat pentingnya struktur pengendalian manajemen harus disusun dan diterapkan pada semua kegiatan perusahaan.

Thomas Sumarsan (2011) Pengendalian manajemen adalah Suatu rangkaian tindakan dan aktivitas yang terjadi pada seluruh kegiatan organisasi dan berjalan secara terus menerus.

Pengendalian manajemen bukanlah suatu sistem terpisah dalam suatu organisasi, melainkan harus dianggap sebagian penting dari setiap sistem yang dipakai manajemen untuk mengatur dan mengarahkan kegiatannya.

Dengan adanya perkembangan teknologi, maka terjadi pula pergeseran dari pengendalian manajemen dalam perusahaan yang menggunakan sistem informasi akuntansi. Dengan adanya pengendalian manajemen dalam sistem informasi akuntansi maka akan lebih mudah diantaranya agar lebih efisien dan selain itu daya yang diolah lebih banyak dan cepat penyaluran informasinya keseluruh tingkat manajemen.

Dimana sistem infomasi akuntasi pada perusahaan jasa konstruksi digunakan untuk perencanaan, pelaksanaan dan evaluasi atas kegiatan yang dilakukan perusahaan yang dinamakan proyek.

Dalam mengevaluasi dan mengendalikan manajemen pimpinan perusahaan membutuhkan suatu sistem informasi yang dapat membantu menyediakan informasi, untuk dapat mengambil langkah-langkah pengambilan keputusan dalam rangka pengendalian manajemen sehingga seluruh kegiatan perusahaan dapat diikuti dan di kendalikannya.
Salah satu informasi yang di butuhkan oleh pimpinan perusahaan adalah informasi yang dihasilkan oleh suatu sistem yang dikenal dengan sistem informasi akuntansi. Melalui proses pengumpulan dan pengolahan data, sistem informasi akuntansi dapat memberikan informasi mengenai kegiatan keuangan yang terjadi dalam perusahaan, dalam bentuk yang disesuaikan dengan kebutuhan masingmasing pihak.

Menurut Sunyoto Gondodiyoto (2007) tujuan atau manfaat/keguanann Sistem informasi akuntansi sebagai berikut:

1. Untuk melakukan pencatatan (rekording) transaksi dengan biaya klerikal seminimal mungkin dan menyediakan informasi (information value added mechanism) bagi pihak intern untuk pengelolaan kegiatan usaha (managers) serta para pihak terkait (stockholder/stakeholdera).

2. Untuk memperbaiki informasi yang dihasilkan oleh sistem yang sudah ada, baik mengenai mutu, ketepatan penyajian maupun struktur informasinya.

3. Untuk menerapkan (implementasi) sistem pengendalian intern, memperbaiki kinerja dan tingkat keandalan (reliability) informasi akuntansi dan untuk menyediakan catatan lengkap mengenai pertanggungjawaban (akuntabilitas).

4. Menjaga/meningkatkan perlindungan kekayaan perusahaan.

Manajemen memerlukan sistem informasi akuntansi guna mencapai tujuan perusahaan. Dalam memenuhi fungsinya, sistem informasi akuntansi harus mempunyai tujuan-tujuan, baik 
tujuan khusus maupun tujuan umum yang keduanya dapat memberikan pedoman kepada manajemen dalam merencanakan suatu sistem yang dapat menghasilkan informasi-informasi yang berguna terutama dalam hal perencanaan dan pengendalian.

Baik buruknya kinerja dari sebuah Sistem Informasi Akuntansi dapat dilihat melalui kepuasan pemakai Sistem Informasi Akuntansi dan pemakaian dari Sistem Informasi Akuntansi itu sendiri. Ada beberapa faktor yang berpengaruh pada kinerja Sistem Informasi Akuntansi, antara lain: Keterlibatan pemakai dalam pengembangan sistem, Kemampuan teknik personal SI, Ukuran organisasi, Dukungan manajemen puncak, formalisasi pengembangan SI, Program pelatihan dan pendidikan pemakai, Keberadaan dewan pengarah SI dan Lokasi departemen SI.

Dalam melaksanakan tugasnya para manajer dan pengambil keputusan lainnya dihadapkan pada situasi yang tidak dapat dipastikan pada masa yang akan datang akibat terjadinya perubahan. Untuk membuat perencanaan dan melakukan pengendalian, maka pihak-pihak yang berkepentingan membutuhkan informasi.

Menurut Sanyoto Gondowiyoto (2007) informasi adalah data yang diolah menjadi bentuk yang lebih berguna, lebih bermanfaat dan lebih berarti bagi yang menerimanya.

George H. Bodnar (2006) mendefinisikan informasi sebagai berikut Informasi merupakan suatu data yang diorganisasi yang dapat mendukung ketepatan pengambilan keputusan. Sedangkan menurut Romney (2006) (dalam Sri Mulyani 2007) mengemukakan informasi yang baik sebagai berikut:

$$
\text { Relevan artinya apabila }
$$

informasi yang termuat didalamnya dapat mempengaruhi keputusan pengguna dengan membantu mereka mengevaluasi peristiwa masa lalu atau masa yang akan datang dan informasi yang relevan adalah informasi yang memiliki manfaat umpan balik dan memiliki manfaat prediktif.

Andal artinya informasi harus bebas dari pengertian yang menyesatkan dan kesalahan material, menyajikan setiap fakta secara jujur, serta dapat diverifikasi.

Lengkap artinya informasi disajikan selengkap mungkin, yaitu mencakup semua informasi yang dapat mempengaruhi pengambilan keputusan.

\begin{tabular}{llr}
\multicolumn{2}{c}{ Tepat Waktu artinya } \\
informasi tersedia pada & saat \\
dibutuhkan dan informasi & yang \\
disajikan terbaru.
\end{tabular}

Dapat Dipahami artinya informasi yang disajikan dalam manajemen keuangan dinyatakan dalam bentuk serta istilah yang disesuaikan dengan batas pemahaman para pengguna.

Dapat Diverifikasi artinya informasi yag disajikan dalam informasi keuangan dapat diuji kebenarannya.

Dapat Diakses artinya informasi tersedia pada saat dibutuhkan dan dengan format yang dapat digunakan.

Atas definisi tersebut diatas maka informasi dapat dijadikan dasar dalam pengambilan keputusan yang tepat. Akuntansi merupakan suatu alat untuk menginformasikan keadaan perusahaan atau organisasi kepada pemakai.

Berdasarkan uraian diatas, maka dilakukanlah penelitian ini untuk mengetahui "Pengaruh Sisitem Informasi Akuntansi Dan Pelaporan Keuangan Terhadap Pengendalian 
Manajemen Pada Perusahaan Jasa Konstruksi (PT. X) di Jakarta." Penelitian ini akan berfokus pada pengendalian manajemen perusahaan pada PT. X yang dipengaruhi oleh Sistem Informasi Akuntansi dan Pelaporan Keuangan.

\section{B. LANDASAN TEORI}

Dalam menjalankan usahanya pimpinan perusahaan tidak terlepas dari sistem informasi guna memberikan masukan serta yang diharapkan dapat mengatisifasi semua perubahan yang menyangkut kegiatan operasional. Untuk itu pimpinan perusahaan membutuhkan informasiinformasi yang penting untuk pengambilan keputusan, salah satu informasi tersebut adalah informasi yang dihasilkan oleh sistem informasi akuntansi.

Azhar Susanto (2008)

mendifinisikan sistem informasi akuntansi adalah Sistem informasi akuntansi dapat didefinisikan sebagai kumpulan (integrasi) dari sub- sub sistem/komponen baik fisik yang saling berhubungan dan bekerja sama satu sama lain secara harmonis untuk mengolah data transaksi yang berkaitan dengan masalah keuangan menjadi informasi keuangan.

George $\mathrm{H}$. Bobnar terjemahan (2006) mendefinisikan sistem informasi akuntansi sebagai berikut Sistem informasi akuntansi (SIA) merupakan kumpulan sumber daya, seperti manusia dan peralatan, yang dirancang untuk mengubah data keuangan dan data lainnya kedalam informasi.

Dari definisi diatas dapat disimpulkan bahwa sistem informasi akuntansi adalah bagian dari organisasi yang mengumpulkan dan mengolah data transaksi keuangan untuk menghasilkan informasi, baik bagi pihak luar maupun pihak dalam perusahaan. Informasi akuntansi adalah bagian terpenting dari seluruh informasi yang diperlukan oleh manajemen karena informasi akuntansi berhubungan langsung dengan data keuangan suatu perusahaan, ada tiga elemen yang terkait dalam definisi tersebut yaitu sistem, informasi dan akuntansi.

\section{Sistem Informasi Akuntansi Perusahaan Konstruksi}

Perusahan konstruksi adalah perusahaan jasa yang menjadi mitra kerja bagi Pemerintah, BUMN, dan Swasta dalam bidang pembagunan insfrastruktur yang disebut proyek. Untuk pekerjaan proyek tersebut ditetapkan suatu harga yang dinamakan kontrak, harga kontrak tersebut besarnya dapat dinegosiasikan dengan memberi kerja atau didasarkan atas suatu pelelangan.

Menurut Peraturan Pemerintah No. 38 tahun 1983 (dalam Ida Bagus Teddy Prinathara 2010) Perusahaan jasa konstruksi adalah perusahaan yang pekerjaannya melaksanakan pembangunan, pembuatan, perbaikan, atau pemugaran bangunan atau barang yang tidak bergerak lainnya, baik untuk kepentingan sendiri maupun atas suruhan pihak lain, dengan atau tanpa perjanjian tertulis. Pekerjaan itu sendiri atas kepentingan sendiri atau suruhan pihak lain dengan melakukan perjanjian tertulis atau disebut dengan kontrak konstruksi.

Dalam suatu proyek, manajemen perusahaan konstruksi menjalankan tiga tahapan sebagaimana dikemukakan oleh Dipohusodo (1996) sebagai berikut : Semua kegiatan proyek merupakan suatu siklus mekanisme manajemen yang didasarkan atas tiga tahapan yaitu; perencanaan, pelaksanaan, dan 
evaluasi.

Pada perusahaan kontruksi untuk pengakuan pendapatan untuk satu periode akuntansi. Dinyatakan dalam Standar Akuntansi Keuangan (SAK) dalam PSAK No.

34 (2009) menyatakan bahwa, Bila hasil (autcome) kontrak konstruksi dapat diestimasi secara andal, pendapatan kontrak dan biaya kontrak yang berhubungan dengan kontrak konstruksi harus diakui masing-masing sebagai pendapatan dan beban dengan memperhatikan tahap penyelesaian aktivitas kontrak pada tanggal neraca (percentage of completion).

Menurut ketentuan tersebut diatas pengakuan pendapatan pada perusahaan konstruksi metode yang digunakan untuk tujuan tersebut dalam rangka pelaporan adalah Metode Persentase penyelesaian (Persentage of completion).

\section{Pelaporan Keuangan}

Pelaporan keuangan merupakan laporan keuangan yang disampaikan oleh manajemen sebagai pertanggungjawaban baik untuk intern maupuan ektern dan laporan keuangan itu sediri merupakan hasil akhir dari proses akuntansi yaitu proses pengkomunikasian laporan. Laporan keuangan merupakan mekanisme yang penting bagi manajer untuk berkomunikasi dengan pihak investor luar yaitu publik diluar lingkup manajemen serta tidak terlibat dalam pengolahan perusahaan. Pihak-pihak yang berkepentingan terhadap laporan keuangan secara garis besar dapat dikatagorikan dalam dua kelompok yaitu pemakai langsung (direct user) dan pemakai tidak langsung (indirect user ).

Kelompok pertama (pemakai langsung) meliputi antara lain ; pemilik, manajer, kreditur, pemasok, pelanggan dan karyawan. Sedangkan kelompok yang kedua mencakup analis sekuritas, penasihat investasi, pengacara dan asosiasi perdagangan.

Meskipun kepentingan masingmasing kelompok pemakai laporan tidak sama tetapi laporan keuangan tidak boleh menyimpang dari aturan yang menghendaki bahwa itu merupakan sumber informasi keuangan yang bersifat umum. Di Indonesia hal ini telah didukung oleh suatu ketentuan yang disebut dengan Standar Akuntansi Keuangan (SAK) yang merupakan pedoman penyusunan laporan keuangan untuk memenuhi kebutuhan yang bersifat umum sehingga tidak sepenuhnya dapat memenuhi informasi setiap pemakai laporan keuangan.

Laporan keuangan juga menanpung catatan dan skedul tambahan serta informasi lainnya. Misalnya, laporan tersebut mungkin menampung informasi tambahan yang relevan dengan kebutuhan pemakai neraca dan laporan laba rugi. Mungkin pula mencakup pengungkapan tentang resiko dan ketidakpastian yang mempengaruhi perusahaan dan setiap sumber daya dan kewajiban (obligation) yang tidak dicantumkan dalam neraca (seperti cadangan mineral). Informasi segmen- segmen industri dan geografi serta pengaruhnya pada perusahaan akibat perubahan harga dapat disediakan dalam bentuk informasi tambahan.

Untuk mencapai tujuannya, laporan keuangan disusun atas dasar akrual. Dengan dasar ini, pengaruh transaksi dan peristiwa lain diakui pada saat kejadian (dan bukan pada saat kas atau setara kas diterima atau dibayar dan di catat dalam catatan akuntansi setra dilaporkan dalam laporan keuangan pada periode yang bersangkutan. Laporan keuangan yang 
disusun atas dasar akurasi memberi informasi kepada pememakai tidak hanya transaksi masa lalu yang melibatkan penerimaan dan pembayaran kas tetapi juga kewajiban pembayaran kas di masa depan serta sumber daya yang mempresentasikan kas yang akan di terima di masa depan. Oleh karena itu, laporan keuangan menyediakan jenis informasi transaksi masa lalu dan peristiwa lainnya yang paling berguna bagi pemakai dalam pengambilan keputusan ekonomi.

\section{Pengendalian Manajemen}

\section{Pengendalian/pengawasan}

dapat didefinisikan sebagai suatu proses untuk "manajemen" bahwa tujuan-tujuan organisasi dan manajemen tercapai. Ini berkenaan dengan cara-cara membuat kegiatan sesuai yang direncanakan.

Menurut Agus Maulana (1992) Pengendalian manajemen terutama adalah Proses untuk memotivasi dan memberi semangat orang-orang yang melaksanakan kegiatan-kegiatan demi mencapai tujuan organisasi.

Menurut Darsono Prawiro \& Ari Purwanti (2009) hakekat manajemen adalah: Membuat keputusan, yaitu memilih alternatif terbaik dari berbagai alternatif informasi yang tersedia yang dapat memberikan maksimun benefit. Keputusan itu meliputi keputusan rutin keputusan khusus. Pengambilan keputusan merupakan suatu tugas pokok dalam perencanaan dan aspek keputusan dalam pengendalian" Proses pengendalian biasanya terdiri paling sedikit lima tahap (langkah) yaitu:

1) penetapan standar pelaksanaan (perencanaan), 2) penetapan pengukuran pelaksanaan kegiatan, 3) pengukuran pelaksanaan kegiatan nyata, 4) pembandingan pelaksanaan kegiatan-kegiatan dengan standar dan penganalisaan penyimpangan- penyimpangan dan 5) pengambilan tindakan koreksi bila perlu .

Pengendalian manajemen bukanlah suatu sistem terpisah dalam suatu organisasi, melainkan harus dianggap sebagai bagian penting dari setiap sistem yang dipakai manajemen untuk mengatur dan mengarahkan kegiatannya. Pengendalian internal dapat disebut pula pengendalian manajemen yang terpasang dalam organisasi dalam sebagai bagian dari serana prasarana organisasi guna membantu manajemen menjalankan organisasi dan mencapai tujuannya.

Committee of Sponsoring Organizations (COSO) (dalam Thomas Sumarsan, 2011) memperkenalkan 5 (lima) elemen kebijakan dan prosedur yang di rancang dan diimplementasikan untuk memberikan jaminan bahwa tujuan pengendalian manajemen akan dapat dicapai. Kelima elemen pengendalian tersebut adalah;

1. Lingkungan Pengendalian (Control Environment)

2. Penilaian Risiko Manajemen (Management Risk Assessment)

3. Sistem Komunikasi dan Informasi (Information and Communication System)

4. Aktivitas Pengendalian (Control Activities)

5. Monitoring

Jadi pengendalian manajemen adalah suatu proses yang digunakan para manajer untuk mempengaruhi anggota lainnya dalam suatu organisasi agar strategi- strategi organisasi dilaksanakan.

Pengendalian manajemen dapat berjalan efektif jika dilaksanakan dengan sungguh-sungguh oleh manusia. Tanggung jawab pengendalian manajemen sangat tergantung pada manajemen. 
Manajemen menetapkan tujuan, merancang dan melaksanakan metode pengendalian, memantau serta mengevaluasi pengendalian.

\section{Sistem Pengendalian Manajemen}

Sistem pengendalian manajemen merupakan suatu rangkaian tindakan dan aktifitas yang terjadi pada seluruh kegiatan organisasi dan berjalan secara terus menerus. Sistem pengendalian manajemen memeiliki beberapa karakteristik pokok yang dapat diuraikan sebagai berikut :

1. Sistem pengendalian manajemen diarahkan pada program-program dan pusatpusat pertanggung jawaban (responsibility ceters).

2. Informasi yang diproses dalam sistem pengendalian manajemen terdiri dari atas dua jenis yaitu : a). Data dalam bentuk program, anggaran, standar. b). Data actual, yaitu yang nyata terjadi baik didalam maupun diluar lingkunagn organisasi.

3. Sistem pengendalian manajemen adalah sistem organisasi total yang merangkum semua aspek dalam operasi organisasi. Fungsinya membentu manajemen memelihara keseimbangan di antara bagian-bagian operasi dan menjalankan organisasi secara terkoordinasi.

4. Sistem pengendalian manajemen berhubungan erat dengan struktur keuangan yang didalamnya kegiatan-kegiatan dan sumber daya organisasi yang dinyatakan dalam satuan uang.

5. Aspek perencanaan dari sistem pengendalian cenderung mengikuti pola dan jadwal tertentu.

6. Sistem pengendalian manajemen merupakan sistem yang terkoordinasi dan terpadu, yakni data yang terkumpul digabungkan untuk saling dibandingkan setiap saat pada setiap unit organisasi. Data aktual disusun secara khusus sesuaidengan format data yang direncanakan sehingga memungkinkan dilakukan perbandingan antar hasil actual dengan hasil yang diinginkan secara konsisten.

Menurut Thomas Sumarsan (2011) Tujuan sistem pengendalian manajemen adalah a). Diperolehnya keandalan dan integritas informasi. b). Kepatuhan pada kebijakan, rencana, prosedur, peraturan, dan ketentuan yang berlaku. c). Melindungi harta perusahaan. d). Pencapaian kegiatan yang ekonomis dan efisiensi

\section{Pemanfaatan Informasi Akuntansi Dalam Pengendalian Manajemen}

Sesuai dengan pengertian yang telah dikemukakan pada bagian sebelumnya, informasi akuntansi adalah informasi yang bersifat keuangan yang berguna untuk pengambilan keputusan dalam suatu organisasi yang berguna untuk pengambilan keputusan dalam suatu organisasi perusahaan, sementara salah-satu karakteristik sistem pengendalian manajemen adalah kaitannya yang erat dengan kegiatankegiatan dan sumber daya organisasi yang dinyatakan dalam satuan uang.

Mengingat dari fenomena tersebut terlihat adanya aspek keuangan yang menjadi titik persinggungan maka secara teoritis sangatlah mungkin dilaksanakan pengendalian manajemen dengan memanfaatkan informasi akuntansi. 


\section{Kerangka Berpikir}

$\begin{array}{ll} & \text { Pengendalian manajemen } \\ \text { dalam suatu organisasi dapat }\end{array}$ dilaksanakan dengan memanfaatkan informasi akuntansi mengingat sistem pengendalian manajemen berhubungan erat dengan struktur keuangan, sementara informasi akuntansi adalah informasi yang bersifat keuangan yang berguna untuk pengambilan keputusan. Bila semakin baik kualitas informasi.

Akuntansi dan laporan keuangan maka akan dapat meningkatkan kualitas pengendalian manajemen.

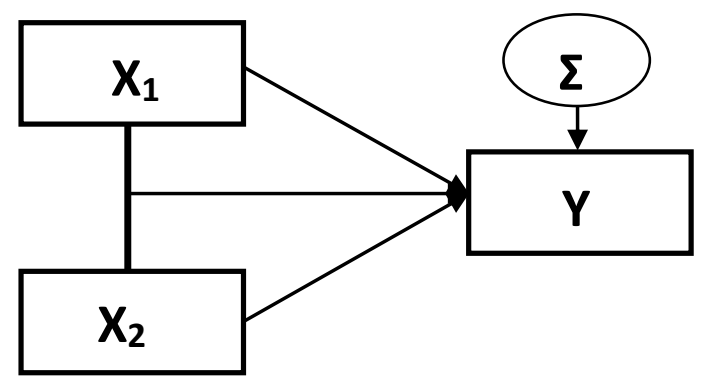

Gambar 2.1 Hubungan Tiga Variabel Keterangan :

$\mathrm{X}_{1}=$ Sistem Informasi Akuntansi (SIA)

$X_{2}=$ Pelaporan Keuangan

$\mathrm{Y}=$ Pengendalian Manajemen

\section{Hipotesis}

Menurut Nanang Martono (2010) Hipotesis adalah sebagai jawaban sementara yang kebenarannya masih harus diuji, atau rangkuman kesimpulan teroretis yang diperoleh dari tinjauan pustaka dan menurut Erwan Agus Purwanto (2007) Hipotesis adalah pernyataan atau dugaan yang bersifat sementara terhadap suatu masalah penelitan yang kebenarannya masih lemah (belum tentu kebenarannya) sehingga harus diuji secara empiris. Dengan demikian hipotesis merupakan jawaban sementara terhadap permasalah yang secara teoritis paling mungkin terjadi. Adapun hipotesisnya yaitu:
1. Bahwa sistem informsi akuntansi berpengaruh terhadap pengendalian manajemen pada PT. X.

2. Bahwa pelaporan keuangan berpengaruh terhadap pengendalian manajemen pada PT. X.

3. Bahwa sistem informasi akuntansi dan pelaporan keuangan secara bersama- sama berpengaruh terhadap pengendalian manajemen PT. $\mathrm{X}$.

\section{METODE PENELITIAN}

\section{Lokasi Penelitian}

Penelitian dilakukan di Jakarta dan direncanakan memakan waktu selama 4 bulan pada perusahaan jasa konstruksi (PT. X) yang berdomisili di Jakarta.

\section{Pendekatan Penelitian}

Penelitian ini menggunakan Penelitian Lapangan (Field Reasearch) dengan menggunakan kombinasi antara data primer dan data sekunder. Data primer diperoleh melalui pendekatan yang berkaitan dengan topik penelitian. Sedangkan data sekunder diperoleh dari obyek penelitian.

\section{Definisi Operasional Variabel Penelitian}

Berdasarkan judul tesis ini yaitu "Pengaruh Sistem Informasi Akuntansi Dan Pelaporan Keuangan Terhadap Pengendalian Manajemen Pada Perusahaan Konstruksi (PT X) Di Jakarta", maka identifiksi variabel independen $(\mathrm{X})$ dan variabel dependen (Y).

1. Variabel bebas atau Independen (X)

Yang menjadi variabel independen adalah Sistem Informasi 
Akuntansi (X1) dan Pelaporan Keuangan (X2). Masalah yang akan dianalisis dalam penelitian ini adalah pengaruh sistem informasi akuntansi dan pelaporan keuangan terhadapa pengendalian manajemen, kualitas informasi akuntansi (X1) dapat dijabarkan dalam lima dimensi yang masing-masing menjadi sub variabel yaitu:

a. Seberapa jauh ketersediaan informasi akuntansi untuk dimanfaatkan (avilability)

b. Seberapa besar informasi akuntansi telah mencerminkan kenyataan yang sebenarnya (accuracy)

c. Seberapa jauh ketepatan waktu perolehan informasi akuntansi (timeliness)

d. Seberapa jauh informasi akuntansi telah memuat semua hal yang diperlukan (completeness)

e. Seberapa kuat hubungan antara informasi akuntansi dengan masalah yang memerlukan informasi berkenaan untuk pemecahannya (relevance).

Sedangkan kualitas pelaporan keuangan (X2) dapat dijabarkan sub variabel berikut:

a. Sejauh mana tingkat kepercayaan terhadap informasi dalam laporan keuangan mengenai sumbersumber ekonomi dan modal suatu perusahaan.

b. Sejauh mana tingkat kepercayaan terhadap informasi yang diberikan dalam pelaporan keuangan mengenai perubahan dalam sumber ekonomi neto suatu perusahaan yang timbul dari aktivitas perusahaan dalam rangka memperoleh laba. c. Sejauh mana kemempuan pengguna laporan dalam mengestimasi potensi perusahaan dalam menghasilkan laba berdasarkan informasi yang tertuang dalam laporan tersebut.

2. Variabel terikat atau dependen (Y)

Yang menjadi variabel dependen (Y) adalah Pengendalian Manajemen, efektivitas pengendalian manajemen dijabarkan dalam empat dimensi yang masing-masing menjadi sub variabel yaitu :

a. Seberapa jauh upaya pengendalian manajemen melalui penerapan konsep pusat-pusat pertanggung jawaban (responsibility centers)

b. Seberapa jauh upaya pengendalian manajemen melalui pemanfaatan hasil pengolahan data terencana dan data aktual

c. Seberapa banyak terdapat persamaan persepsi tentang tujuan organisasi antara para manajer pusat-pusat pertanggungjawaban dengan manajer puncak.

\section{Populasi dan Sampel Penelitian Populasi}

Populasi merupakan keseluruhan objek atau subjek yang berada pada suatu wilayah dan memenuhi syarat-syarat tertentu berkaitan dengan masalah penelitian, atau keseluruhan unit atau individu dalam ruang lingkup yang akan diteliti. Dalam penelitian ini yang diteliti adalah Pengurus/karyawan pada perusahaan jasa konstruksi (PT. X) di Jakarta dengan klasifikasi gred 7 . Klasifikasi Gred 7 adalah perusahaan 
yang mempunyai kemampuan mengerjakan proyek dari nilai $\mathrm{Rp}$ 50.000.000.000,- (lima puluh milyar rupiah) sampai tak terhingga, jumlah sampel dalam penelitian ini lebih kurang 30 orang responden pada tingkat jabatan Staff, manajer dan direktur (pengurus).

\section{Sampel Penelitian}

Teknik sampel yang digunakan dalam penelitian ini adalah purposive sampel. Purposive sampel yaitu pengambilan sampel berdasarkan keperluan penelitian. Artinya setiap unit/individu yang diambil dari populasi dipilih dengan sengaja berdasarkan pertimbangan tertentu. Penilaian yang digunakan dalam menentukan sampel dalam penelitian ini yaitu Karyawan dan Pimpinan yang berhubungan dengan Manajemen Keuangan Unit Organisasi perusahaan.

\section{Tehnik Pengumpulan Data}

Menurut Erwan Agus Purwanto \& Dyah Ratih Sulistyastuti Sugiono (2007) Data memiliki peran senteral dalam penelitian karena penelitian, intinya adalah mengumpulkan data, artinya tanpa data tidak akan ada penelitian, dan data yang digunakan dalam suatu penelitian harus benar, jika data yang digunakan tidak benar maka menghasilkan informasi yang salah.

Dalam penelitian ini tehnik pengumpulan data adalah sebagai berikut :

1. Data Primer

Yaitu data yang dikumpulkan secara langsung dari lapangan penelitian, dan data ini dikumpulkan dengan cara mengisi angket (kuesioner) kepada responden dalam hal ini karyawan dan pimpinan perusahaan.

2. Data Sekunder
Yaitu data yang diperoleh melalui penelitian terdahulu yang dilakukan oleh pihak lain, misalkan dari dokumen, studi pustaka yang ada hubungannya dengan masalah yang sedang diteliti dan pengamatan di lapangan.

3. Cara Pengukuran Pengukuran besaran variabel dilakukan dengan Skala Likert, responden diminta mengisi pernyataan sikap atau penilaian terhadap sesuatu misalnya setuju-tidak setuju atau senang-tidak senang, dan dari masingmasing jawaban akan di berikan skor nilai tersaji pada tabel 3.1

Tabel 3.1

Skala Likert

\begin{tabular}{|l|l|}
\hline Sangat Tidak Setuju & 1 \\
\hline Tidak Setuju & 2 \\
\hline Cukup Setuju & 3 \\
\hline Setuju & 4 \\
\hline Sangat Setuju & 5 \\
\hline
\end{tabular}

Berdasarkan skor nilai tersebut dapat diukur besarnya masing-masing variabel dari sampel penelitian melalui penjumlahan nilai setiap responden. Jumlah pertanyaan masing variabel adalah 15 buah.

\section{Metode Analisis Data}

Dalam menganalisis data, uji statistik yang digunakan adalah nalisis korelasi, analisis regresi berganda, analisis koefisiensi determinasi, dan dengan bantuan komputer Program SPSS

1. Analisis untuk mendiskripsikan data variabel

Analisis statistik diskriptif digunakan untuk mencari harga ratarata, simpang baku, nilai minimum dan nilai maksimum serta pembuatan grafik histogramnya. Analisis korelasi yaitu analisis ini digunakan untuk mengetahui keeratan hubungan/derajat hubungan variabel independen (Sistem 
Informasi Akuntansi dan Pelaporan Keuangan) terhadap variabel dependen (Pengendalian Manajemen).

2. Analisis korelasi yaitu analisis ini digunakan untuk mengatahui keeratan hubungan variabel independen (Sistem Informasi Akuntansi dan Pelaporan Keuangan) terhadap variabel dependen (Pengendalian Manajemen).

3. Analisis Regresi Sederhana Analisis regresi sederhana digunakan untuk memprediksi atau meramalkan hubungan antara variabel penelitian dan dinyatakan dalam bentuk garis persamaan.

$$
\mathbf{Y}=\mathbf{a}+\mathbf{b} 1 \mathrm{X} 1+\mathbf{b} 2 \mathrm{X} 2+\mathbf{E}
$$

Dimana: $\mathrm{Y}=$ Pengendalian Manajemen

a $=$ Intercept (konstanta) untuk setiap Y

$\mathrm{b}=$ Koefisien regresi untuk tiap $\mathrm{Y}$

$\mathrm{X} 1=$ Sistem Informasi Akuntansi

$\mathrm{X}_{2}=$ Pelaporan Keuangan

$\mathrm{E}=$ Kesalahan baku untuk Y

4. Analisis Koefisien Determinasi Analisis ini digunakan untuk mengetahui sampai berapa besar sumbangan variabel independen terhadap variabel dependen. Koefisien determinasi merupakan kuadrat dari koefisien korelasi berganda $\left(\mathrm{R}^{2}\right)$ yang dalam penggunaannya dinyatakan dalam prosentase $(\%)$.

\section{Koefisien determinasi $=r^{2} \times 100 \%$}

1. Komputerisasi

Untuk lebih memudahkan analisis data secara tehnis dan juga memenfaatkan hasil nyata teknologi canggih, data dimasukkan diproses oleh komputer program SPSS(Statistical Product and Service Solutions) kemudian baru dilakukan analisis makna dari hasil perhitungan.

Untuk menguji ada tidaknya pengaruh antara Sistem Informasi Akuntansi dan Pelaporan Keuangan dengan Pengendalian Manajemen dilakukan hipotesis untuk menguji koefisien korelasi dan regresi sederhana dari hasil pembuktian hipotesis pertama, kedua dan hipotesis ketiga dalam penelitian ini.

a. Formula Hipotesis

Ho $=$ Kedua variabel tidak ada pengaruh satu dengan yang lain.

$\mathrm{Ha}=$ Kedua variabel ada hubungan yang signifikan satu dengan yang lain

$\mathrm{H} 1=$ Terdapat

pengaruh positif dan signifikan Sistem Informasi Akuntansi terhadap Pengendalian Manajemen.

$\mathrm{H}_{2}=$ Terdapat pengaruh positif dan signifikan Pelaporan Keuangan terhapat Pengendalian Manajemen.

H3 = Terdapat pengaruh yang positif dan signifikan Sistem Informasi Akuntansi dan Pelaporan Keuangan terhadap Pengendalian Manajemen.

b. Mencari t hitung : $a=5 \%$, $\mathrm{n}=30$

c. Pengambilan kesimpulan :

Jika $\mathrm{t}$ hitung $>\mathrm{t}$ table, maka $\mathrm{Ho}$ ditolak dan $\mathrm{H} 1$ diterima, berarti kedua variabel tidak ada hubungan satu dengan yang lain. Jika $\mathrm{t}$ hitung $<\mathrm{t}$ tabel, maka Ho diterima dan $\mathrm{H} 1$ ditolak, berarti kedua variabel ada hubungan yang signifikan satu dengan yang lain.

\section{HASIL PENELITIAN DAN PEMBAHASAN}

\section{Hasil Penelitian}

\section{Pengujian Persyaratan Analisis}

\section{Uji Kualitas Data}

Pada penelitian ini data yang digunakan dalam uji kualitas data 
berasal dari kuesioner baik pada variabel independen atau variabel bebas yaitu variabel Sistem Informasi Akuntasi dan Laporan Keuangan serta variabel dependen (terikat) yaitu Pengendalian Manajemen.

\section{Uji Validitas}

Hasil pengujian validitas dilakukan untuk mengukur sah atau valid tidaknya suatu kuesioner. Hasil uji validitas didapat dari hasil pengolahan melalui program SPSS versi.

a. Variabel Sistem Informasi Akuntansi (X1)

Hasil uji validitas terhadap 15 butir pernyataan responden pada variabel Sistem Informasi Akuntansi (X1) dengan korelasi Pearson Product Moment tersaji pada tabel 4.1

\section{Tabel 4.1}

Hasil Uji Coba Variabel X1

\begin{tabular}{|c|c|c|c|}
\hline No. Butir & Rhitung & rtabel & Keterangan \\
\hline Q1 & 0.607 & 0.514 & Valid \\
\hline Q2 & 0.315 & 0.514 & Tidak Valid \\
\hline Q3 & 0.637 & 0.514 & Valid \\
\hline Q4 & 0.867 & 0.514 & Valid \\
\hline Q5 & 0.805 & 0.514 & Valid \\
\hline Q6 & 0.685 & 0.514 & Valid \\
\hline Q7 & 0.680 & 0.514 & Valid \\
\hline Q8 & 0.801 & 0.514 & Valid \\
\hline Q9 & 0.620 & 0.514 & Valid \\
\hline Q10 & 0.819 & 0.514 & Valid \\
\hline Q11 & 0.825 & 0.514 & Valid \\
\hline Q12 & 0.600 & 0.514 & Valid \\
\hline Q13 & 0.584 & 0.514 & Valid \\
\hline Q14 & 0.468 & 0.514 & Tidak Valid \\
\hline Q15 & 0.083 & 0.514 & Tidak Valid \\
\hline & Cronbach's Alpha $=0,910$ \\
\hline
\end{tabular}

Dilihat dari hasil uji validitas di atas menunjukkan bahwa semua butir instrumen kuesioner untuk variabel Sistem Informasi Akuntansi (X1) mempunyai korelasi yang lebih besar yakni Q1, Q3 sampai dengan Q13 di atas $\mathrm{r}$ tabel 0.514 maka dapat disimpulkan 12 butir pada variabel $\mathrm{X} 1$ berada pada kondisi rhitung > rtabel sedangkan butir Q2, Q14 dan Q15 berada kondisi rhitung < rtabel maka butir tersebut dinyatakan tidak valid atau gugur.

\section{b. Variabel Pelaporan Keuangan (X2)}

Hasil uji coba terhadap 15 butir pernyataan responden pada variabel X2 dengan menggunakan korelasi Product Moment tersaji pada tabel 4.2

Tabel 4.2

Hasil Uji Coba Variabel X2

\begin{tabular}{|c|c|c|c|}
\hline No. Butir & Rhitung & rtabel & Keterangan \\
\hline Q1 & 0.805 & 0.514 & Valid \\
\hline Q2 & 0.927 & 0.514 & Valid \\
\hline Q3 & 0.776 & 0.514 & Valid \\
\hline Q4 & 0.754 & 0.514 & Valid \\
\hline Q5 & 0.493 & 0.514 & Tidak Valid \\
\hline Q6 & 0.753 & 0.514 & Valid \\
\hline Q7 & 0.819 & 0.514 & Valid \\
\hline Q8 & 0.904 & 0.514 & Valid \\
\hline Q9 & 0.743 & 0.514 & Valid \\
\hline Q10 & 0.791 & 0.514 & Valid \\
\hline Q11 & 0.796 & 0.514 & Valid \\
\hline Q12 & 0.934 & 0.514 & Valid \\
\hline Q13 & 0.558 & 0.514 & Valid \\
\hline Q14 & 0.530 & 0.514 & Valid \\
\hline Q15 & 0.776 & 0.514 & Valid \\
\hline Cronbach's Alpha & 0.955 \\
\hline
\end{tabular}

Dari perhitungan data variabel X2 dengan menggunakan korelasi Product Moment diperoleh hasil, 14 butir instrumen kuesioner yaitu Q1 sampai dengan Q4 dan Q6 sampai dengan Q15 untuk variabel Pelaporan Keuangan (X2) mempunyai 
korelasi yang lebih besar yakni di atas r tabel 0.514 maka dapat disimpulkan 14 butir pernyataan tersebut dinyatakan valid, sedangkan 1 butir pernyataan yaitu Q5 berada pada posisi rhitung < rtabel maka di nyatakan tidak valid.

$$
\begin{aligned}
& \text { c. Variabel Pengendalian } \\
& \text { Manajemen }(\mathrm{Y})
\end{aligned}
$$

butir pernyataan variabel Pengendalian Manajemen (Y) tersaji pada tabel 4.3

\section{Tabel 4.3}

Hasil Uji Coba Variabel Y

\begin{tabular}{|c|c|c|c|}
\hline $\begin{array}{c}\text { No. } \\
\text { Butir }\end{array}$ & rhitung & rtabel & Keterangan \\
\hline Q1 & 0.909 & 0.514 & Valid \\
\hline Q2 & 0.909 & 0.514 & Valid \\
\hline Q3 & 0.867 & 0.514 & Valid \\
\hline Q4 & 0.807 & 0.514 & Valid \\
\hline Q5 & 0.774 & 0.514 & Valid \\
\hline Q6 & 0.815 & 0.514 & Valid \\
\hline Q7 & 0.811 & 0.514 & Valid \\
\hline Q8 & 0.712 & 0.514 & Valid \\
\hline Q9 & 0.842 & 0.514 & Valid \\
\hline Q10 & 0.714 & 0.514 & Valid \\
\hline Q11 & 0.589 & 0.514 & Valid \\
\hline Q12 & 0.845 & 0.514 & Valid \\
\hline Q13 & 0.599 & 0.514 & Valid \\
\hline Q14 & 0.741 & 0.514 & Valid \\
\hline Q15 & 0.932 & 0.514 & Valid \\
\hline \multicolumn{4}{|c|}{ Consbach's Alpha $=0,965$} \\
\hline
\end{tabular}

Dari tabel di atas, terlihat bahwa butir Q1 sampai Q15 0 berada pada posisi rhitung > rtabel, maka ke 15 butir pernyataan tersebut dinyatakan valid.

3. Uji Reliabilitas

Uji Reliabilitas dilakukan untuk menunjukkan konsistensi suatu alat pengukur di dalam mengukur gejala yang sama. Hasil uji reliabilitas dalam penelitiian ini didapat dari hasil pengolahan SPSS, dan hasil uji reliabilitas terhadap ketiga variabel dengan koefisien Alfa Cronbach berdasarkan tabel reakapitulasi diatas, diketahui untuk variabel X1 mempunyai nilai sebesar 0.910 , variabel $\mathrm{X}_{2}$ memiliki nilai reabilitas sebesar 0.955 dan variabel $\mathrm{Y}$ memiliki nilai reabilitas sebesar 0.965 . Hal ini berarti bahwa pernyataan responden pada ketiga variabel tersebut memiliki nilai kurang dari 10, yang artinya ketiga variabel tersebut memiliki keandalan dan penelitian ini dapat dilanjutkan.

4. Uji Linieritas Data

Uji linieritas dilakukan sebelum analisis regresi yang ditujukan untuk menguji apakah dalam sebuah regresi, variabel terikat dan bebas berada pada garis diagonal membentuk lineritas. Model regresi yang baik beredar pada garis diagonal. Dengan program SPSS uji ini dapat dilakukan dengan menggunakan model Normal Probability Plot (NPP)

\section{a. Sistem Informasi Akutansi (X1)}

Dalam uji linieritas variabel Sistem Informasi Akutansi (X1) terhadap Pengendalian Manajemen (Y) dapat dilihat pada gambar grafik yang memperlihatkan bahwa sebaran data (titik-titik) menyebar dari sekitar garis diagonal serta penyebarannya mengikuti garis diagonal berarti bahwa model regresi layak digunakan untuk memprediksi variabel pengendalian manajemen $(\mathrm{Y})$ berdasarkan masukan variabel Sistem Informasi Akutansi (X1), dan jika data menyebar di sekitar garis diagonal dan mengikuti garis diagonal maka model regresi memenuhi asumsi linier.

b. Pelaporan Keuangan (X2)

Hasil pengolahan data pada variabel Pelaporan Keuangan (X2) 
dihasilkan pada gambar grafik yang memperlihatkan bahwa sebaran data (titik-titik) menyebar dari sekitar garis diagonal serta penyebarannya mengikuti garis diagonal berarti bahwa model regresi layak digunakan untuk memprediksi variabel Pengendalian Manajemen (Y) berdasarkan masukan variabel Pelaporan Keuangan (X2), dan jika data menyebar di sekitar garis diagonal dan mengikuti garis diagonal maka model regresi memenuhi asumsi linier.

5. Uji Multikolinearitas

Dari hasil pengolahan data statistik diperoleh tabel pengujian multikolinearitas tersaji pada tabel 4.4

\section{Tabel 4.4}

Hasil Uji Multikolinearitas

\begin{tabular}{|l|l|l|}
\hline UJI MODEL & VIF & Kesimpulan \\
\hline $\begin{array}{l}\text { Sistem Informasi } \\
\text { Keuangan } \\
\text { Pelaporan } \\
\text { Keuangan }\end{array}$ & 1.000 & $\begin{array}{l}\text { tidak ada } \\
\text { multikolinaritas } \\
\text { tidak ada } \\
\text { multikolinaritas }\end{array}$ \\
\hline
\end{tabular}

Dari tabel diatas dapat dilihat bahwa seluruh nilai VIF untuk setiap variable independen dari model yang digunakan dalam penelitian tidak mengandung multikolinearitas (mempunyai VIF < 10). Dengan demikian dapat disimpulkan bahwa model multiple regression yang digunakan terhindar dari masalah multikolinearitas.

6. Uji Heteroskedastisitas Heteroskedastisitas menunjukkan bahwa varians dari setiap error bersifat heterogen yang berarti melanggar asumsi klasik yang mensyaratkan bahwa varians dari error harus bersifat homogen.

Langkah-langkah pengujian heteroskedastisitas :
Ho : tidak ada heteroskedastisitas

Ha : ada heteroskedastisitas

Keputusan :

Jika signifikansi (probabilitas) dari $\mathrm{t}<0.05$ Ho ditolak Jika signifikansi (probabilitas) dari $\mathrm{t}>0.05$ Ho diterima

Tabel 4.5

Hasil Uji Heteroskedasitas dengan Regresi Linier

\begin{tabular}{|l|l|l|}
\hline UJI MODEL & Thitung & Kesimpulan \\
\hline $\begin{array}{l}\text { Sistem Informasi } \\
\text { Akuntansi } \\
\text { Pelaporan } \\
\text { Keuangan }\end{array}$ & 12.386 & Diterima \\
\hline
\end{tabular}

Sistem Informasi Akutansi 3.193 (0.003) dengan demikian (Ha) diterima Pelaporan Keuangan 12.386 (0.000) dengan demikian (Ha) diterima Dengan demikian, Sistem Informasi Akutansi dan Pelaporan keuangan tidak terdapat heterokedasitas.

7. Uji Autokorelasi

Uji autokorelasi bertujuan untuk menguji apakah dalam suatu model regresi linier terdapat korelasi antara kesalahan pengganggu pada periode tertentu dengan kesalahan pengganggu sebelumnya. Jenis pengujian yang umumnya digunakan disebut sebagai statistik DurbinWatson.

Autokorelasi menunjukkan bahwa ada korelasi antara error dengan error periode sebelumnya di mana pada asumsi klasik hal ini tidak boleh terjadi. Permasalahan autokorelasi hanya relevan digunakan jika data yang dipakai adalah data time series sedangkan untuk data cross-section tidak perlu dilakukan.

8. Uji Normalitas

Pengujian data dengan menggunakan uji normalitas dengan 
menggunakan uji KlomogorovSmirnov, berdasarkan hasil pengolahan data pada variabel Sistem Informasi Akutansi dengan hasil bahwa Zhitung $0.701<$ Ztabel maka distribusi variabel Sistem Informasi Akuntansi normal. Nilai variablel Pelaporan Keuangan Zhitung $0.578<$ Ztabel maka distribusi variabel Pelaporan Keuangan dalam kondisi normal. Nilai variablel Pengendalian Manajemen, Zhitung $1.236<$ Ztabel maka distribusi variabel Pengendalian Manajemen dalam kondisi normal.

\section{Analisis Pengaruh Sistem Informasi Akutansi (X1) dan Pelaporan Keuangan (X2) terhadap Pengendalian Manajemen (Y)}

Hasil pengujian korelasi pada variabel Sistem Informasi Akuntansi diperoleh nilai $r=0,688$, variabel Pelaporan Keuangan memiliki nilai $\mathrm{r}=$ 0.955 dan variabel Pengendalian Manajemen memiliki nilai $\mathrm{r}=0.959$, seperti yang tersaji dalam tabel 4.6
Dan ada tidaknya pengaruh Sistem Anformasi Akuntani dan Pelaporan Keuangan terhadap Pengendalian Manajemen, dapat dilihat pada analisis berikut;

1. Ada Pengaruh Sistem Informasi Akutansi (X1) terhadap Pengendalian Manajemen (Y) Dari perhitungan ada tidaknya pengaruh Sistem Informasi Akutansi (X1) terhadap Pengendalian Manajemen (Y), diperoleh $r=0.517$. Besarnya pengaruh adalah sebesar 26,7\% atau $0.517^{2} \times 100 \%=26,7 \%$ sedangkan sisanya sebesar $73.3 \%$ tidak di analisis dalam penelitian ini. Dengan

demikian dapat dikatakan bahwa ada pengaruh yang positif antara Sistem Informasi Akutansi (X1) terhadap Pengendalian Manajemen (Y).

2. Ada Pengaruh Pelaporan Keuangan (X2) terhadap

Tabel 4.6

Hasil Uji Korelasi Variabel X1, X2, Y

\section{Correlations}

\begin{tabular}{|ll|l|l|l|l|}
\hline & & $\begin{array}{l}\text { Sistem } \\
\text { Informasi } \\
\text { Akuntansi }\end{array}$ & $\begin{array}{l}\text { Pelaporan } \\
\text { Keuangan }\end{array}$ & $\begin{array}{l}\text { Pegendalian } \\
\text { Manajemen }\end{array}$ & t1 \\
\hline Sistem Informasi & Pearson Correlation & 1 & $.497 * *$ & $.517 * *$ & $.688 * *$ \\
Akuntansi & Sig. (2-tailed) & .005 & .003 & .000 \\
& N & 30 & 30 & 30 & 30 \\
\hline Pelaporan Keuangan & Pearson Correlation & $.497 * *$ & 1 & $.920 * *$ & $.955 * *$ \\
& Sig. (2-tailed) & .005 & .30 & .000 & 30 \\
& N & 30 & 30 & 30 & 30 \\
\hline Pegendalian & Pearson Correlation & $.517 * *$ & $.920 * *$ & 1 & $.959 * *$ \\
Manajemen & Sig. (2-tailed) & .003 & .000 & .000 \\
& N & 30 & 30 & 30 & 30 \\
\hline t1 & Pearson Correlation & $.688 * *$ & $.955 * *$ & $.959 * *$ & 1 \\
& Sig. (2-tailed) & .000 & .000 & .000 & 30 \\
\hline
\end{tabular}

**. Correlation is significant at the 0.01 level (2-tailed). 
Pengendalian Manejemen (Y). Adapun pengaruh Pelaporan Keuangan (X2) terhadap Pengendalian Manajemen (Y) dapat dilihat pada tabel hasil perhitungan dengan menggunakan korelasi Product Moment yakni sebesar $\mathrm{r}=$ 0.920. Besarnya pengaruh Pelaporan Keuangan (X2) terhadap Pengendalian Manajemen (Y) adalah sebesar $84,6 \%$ atau $0.920^{2} \times 100 \%=$ $0.846 \times 100 \%=84,6 \%$, sedangkan sisanya sebesar $15,4 \%$ tidak dianalisis dalam penelitian ini.

3. Ada pengaruh Sistem Informasi Akutansi (X1) dan Pelaporan Keuangan (X2) secara bersamasama terhadap Pengendalian Manajemen (Y) Adapun pengaruh Sistem Informasi Akutansi (X1) dan Pelaporan Keuangan (X2) secara bersamasama terhadap Pengendalian Manajemen (Y) adalah sebesar 0.850 seperti tersaji pada tabel 4.7

\section{Tabel 4.7}

Model Summary $b$

\begin{tabular}{|c|c|c|c|c|c|}
\hline Model & $\mathrm{R}$ & $\begin{array}{c}\mathrm{R} \\
\text { Square }\end{array}$ & $\begin{array}{c}\text { Adjusted } \\
\mathrm{R} \text { Square }\end{array}$ & $\begin{array}{c}\text { Std. Error } \\
\text { of the } \\
\text { Estimate }\end{array}$ & $\begin{array}{c}\text { Durbin- } \\
\text { Watson }\end{array}$ \\
\hline 1 & $.922^{\mathrm{a}}$ & .850 & .839 & 4.40710 & 2.154 \\
\hline
\end{tabular}

a. Predictors: (Constant), Pelaporan Keuangan, Sistem Informasi Akuntansi

b. Dependent Variable:

Pegendalian Manajemen

\section{Pengujian Hipotesis}

Berdasarkan hasil analisis data tersebut diatas maka dapat dilakukan pengujian hipotesis terhadap pengaruh variabel Sistem Informasi Akutansi (X1) terhadap Pengendalian Manajemen (X2) atau pengaruh Pelaporan Keuangan (X2) terhadap Pengendalian Manajemen dan pengaruh Sistem Informasi Akutansi (X1) dan Pelaporan Keuangan (X2) secara bersama-sama terhadap Pengendalian Manajemen seperti tersaji pada tabel 4.8

\section{Uji Hipotesis Pertama}

\section{Tabel 4.8}

Model Summary $b$

\begin{tabular}{|c|c|c|c|c|c|}
\hline Model & $\mathrm{R}$ & $\begin{array}{c}\mathrm{R} \\
\text { Square }\end{array}$ & $\begin{array}{c}\text { Adjusted } \\
\text { R Square }\end{array}$ & $\begin{array}{c}\text { Std. Error } \\
\text { of the } \\
\text { Estimate }\end{array}$ & $\begin{array}{c}\text { Durbin- } \\
\text { Watson }\end{array}$ \\
\hline 1 & $.517^{\mathrm{a}}$ & .267 & .241 & 9.58024 & 1.939 \\
\hline
\end{tabular}

a. Predictors: (Constant ), Sistem Informasi Akuntansi

b. Dependent Variable: Pegendalian Manajemen

Nilai korelasi antara Sistem Informasi Akutansi (X1) terhadap Pengendalian Manajemen (Y) sebesar $\mathrm{r}$ $=0.517$ dan nilai coefisien determinan sebesar $0.267\left[(0.517)^{2} \times 100 \%=\right.$ $26.7 \%$ ] dengan demikian variabel peningkatan atau penurunan variabel Pengendalian Manajemen dapat dijelaskan oleh variabel Sistem Informasi Akutansi sebesar $26.7 \%$ dengan demikian faktor-faktor lain diluar kedua variabel sebesar $73.3 \%$ dan hal tersebut tidak dijelaskan lebih lanjut dalam penelitian ini. 
Tabel 4.9

Hasil Uji Regresi Linier

Coefficientsa

\begin{tabular}{|c|c|c|c|c|c|c|c|}
\hline \multirow{2}{*}{ Model } & \multicolumn{2}{|c|}{$\begin{array}{l}\text { Unstandardized } \\
\text { Coefficients }\end{array}$} & \multirow{2}{*}{$\begin{array}{c}\text { Standardized } \\
\text { Coefficients } \\
\text { Beta }\end{array}$} & \multirow{2}{*}{$\mathrm{t}$} & \multirow{2}{*}{ Sig. } & \multicolumn{2}{|c|}{$\begin{array}{l}\text { Collinearity } \\
\text { Statistics }\end{array}$} \\
\hline & B & Std. Error & & & & Tolerance & VIF \\
\hline $\begin{array}{ll}\text { 1. } & \text { Constant) } \\
\text { Sistem } \\
\text { Informasi } \\
\text { Akuntansi }\end{array}$ & $\begin{array}{c}15.449 \\
.884\end{array}$ & $\begin{array}{c}10.170 \\
.277\end{array}$ & .517 & $\begin{array}{l}1.519 \\
3.193\end{array}$ & $\begin{array}{l}.140 \\
.003\end{array}$ & 1.000 & 1.000 \\
\hline
\end{tabular}

a. Dependent Variable: Pegendalian Manajemen

$\mathrm{Y}=15.440+0.884 \mathrm{X} 1$ Variabel

Sistem Informasi Akuntansi terhadap

Pengendalian Manajemen (1)

Dengan demikian nilai constanta sebesar 15.449 merupakan nilai murni variabel Pengendalian Manajemen (Y) tanpa dipengaruhi oleh variabel Sistem Informasi Akutansi (X1), sedangkan nilai regresi 0.884 merupakan kontribusi positif dihasilkan oleh variabel Sistem Informasi Akutansi (X1), artinya bila variabel Sistem Informasi Akutansi (X1) ditingkatkan sebesar 1 point maka akan diikuti penguatan terhadap variabel Pengendalian Manajemen (Y) sebesar nilai regresi.

Uji hipotesis diketahui sebesar thitung 3.193 di mana tabel sebesar 2.048 (dua pihak) dengan demikian [thitung $3.193>$ ttabel 2.048] maka (Ho) diterima dan (Ha) ditolak artinya ada pengaruh positif dan signifikan antara Sistem Informasi Akutansi (X1) terhadap Pengendalian Manajemen (Y).

Probabilitas hasil sebesar 0.003 di mana nilai $\square \square=0,05$ atau $5 \%$ dengan demikian probabilitas jauh di bawah nilai alpha atau $0.003<0.05$ dengan demikian pengaruh variabel Sistem Informasi Akutansi (X1) terhadap Pengendalian Manajemen adalah signifikan.

Hasil penelitian ini mendukung hipotesis pertama bahwa sistem informasi akuntansi berpengaruh terhadap pengendalian manajemen pada PT. X. Hal ini berarti bahwa pengendalian manajemen dapat dicapai jika informasi akuntansi yang di terima dapat mencerminkan kondisi yang sebenarnya artinya informasi tersebut harus Relevan, Andal, Lengkap, Tepat waktu, Dapat dipahami dan Dapat diverifikasi. Berdasarkan hasil pengujian signifikan dimana nilai $\mathrm{r}=$ 0.517 dan nilai cofisien determinan sebesar $26.7 \%$, serta besarnya thitung 3.193 sebesar 0.005 lebih kecil dari 0.05 berarti Ho ditolak yang sesuai dengan rumus hipotesis berarti terdapat pengaruh signifikan Sistem Informasi akuntansi terhadap Pengendalian Manajemen pada derajat kepercayaan $26.7 \%$.

2. Uji Hipotesis Ke Dua 
Tabel 4.10

Hasil Uji Korelasi

Model Summaryb

\begin{tabular}{|c|c|c|c|c|c|}
\hline Model & $\mathrm{R}$ & $\begin{array}{l}\mathrm{R} \\
\text { Square }\end{array}$ & $\begin{array}{l}\text { Adjusted } \\
\text { R Square }\end{array}$ & $\begin{array}{l}\text { Std. Errol } \\
\text { of the } \\
\text { Estimate }\end{array}$ & $\begin{array}{l}\text { Durbin- } \\
\text { Watson }\end{array}$ \\
\hline 1 & $.920^{\mathrm{a}}$ & .846 & .840 & 4.39561 & 2.179 \\
\hline
\end{tabular}

a. Predictors: (Constant),Pelaporan Keuangan

b. Dependent

Pegendalian Manajemen

Terhadap hasil pengolahan data pada uji korelasi untuk variabel Pelaporan Keuangan (X2) dengan Pengendalian Manajemen (Y) sebesar 0.920 dengan demikian ada hubungan positif antar variabel artinya bila variabel Pelaporan Keuangan (X2) ditingkatkan maka akan diikuti penguatan variabel Pengendalian Manajemen. Nilai coefisien determinan sebesar $84.6 \%\left[(0.920)^{2} \times 100=\right.$ $84.6 \%$ ] sehingga variasi peningkatan atau penurunan variabel Pengendalian Manajemen dapat dijelaskan oleh variabel Pelaporan Keuangan sebesar $84.6 \%$ sehingga faktor-faktor lain di luar kedua variabel sebesar $15.4 \%$ dan hal tersebut tidak dijelaskan lebih lanjut.

$$
\mathrm{Y}=11.828+0.891 \mathrm{X}_{2} \text { Variabel }
$$

Pelaporan Keuangan terhadap

Pengendalian Manajemen (2)

Dengan demikian nilai constanta sebesar 11.828 merupakan nilai murni variabel Pengendalian Manajemen tanpa dipengaruhi oleh variabel Pelaporan Keuangan (X2) sedangkan nilai regresi 0.891 merupakan kontribusi dihasilkan oleh variabel Laporan Keuangan (X2), artinya bila variabel Pelaporan Keuangan lebih ditingkatkan lagi sebesar 1 point maka akan diikuti penguatan terhadap variabel Pengendalian Manajemen sebesar nilai regresi.

Uji hipotesis diketahui sebesar thitung 12.386 dimana tabel sebesar 2.048 (dua pihk) dengan demikian [thitung $12.386>$ ttabel2.048] maka (Ha) diterima artinya ada pengaruh positif Pelaporan Keuangan (X2) terhadap Pengendalian Manajemen (Y).

Probabilitas hasil sebesar 0.000 dimana nilai $\square \square=0,05$ atau $5 \%$ dengan demikian probabilitas jauh di

Tabel 4.11

Hasil Uji Regresi Linier

Coefficients ${ }^{\mathbf{a}}$

\begin{tabular}{|c|c|c|c|c|c|c|c|}
\hline \multirow[b]{2}{*}{ Model } & \multicolumn{2}{|c|}{$\begin{array}{l}\text { Unstandardized } \\
\text { Coefficients }\end{array}$} & \multirow{2}{*}{$\begin{array}{c}\text { Standardized } \\
\text { Coefficients }\end{array}$} & \multirow[b]{2}{*}{$\mathrm{t}$} & \multirow[b]{2}{*}{ Sig. } & \multicolumn{2}{|c|}{$\begin{array}{c}\text { Collinearity } \\
\text { Statistics }\end{array}$} \\
\hline & B & $\begin{array}{l}\text { Std. } \\
\text { Error }\end{array}$ & & & & \begin{tabular}{|l|} 
Tolerance \\
\end{tabular} & VIF \\
\hline $\begin{array}{l}\text { 1. (Constant) } \\
\text { Pelaporan } \\
\text { Keuangan }\end{array}$ & $\begin{array}{c}11.828 \\
.891\end{array}$ & $\begin{array}{c}2.985 \\
.072\end{array}$ & .920 & $\begin{array}{c}3.963 \\
12.386\end{array}$ & $\begin{array}{l}.000 \\
.000\end{array}$ & 1.000 & 1.000 \\
\hline
\end{tabular}

a. Dependent Variable: Pegendalian Manajemen 
bawah nilai alpha dengan demikian variabel Pelaporan Keuangan (X2) berpengaruh secara signifikan terhadap Pengendalian Manajemen dalam PT. "X".

Hasil penenelitian tersebut diatas mendukung hipotesis ke dua terdapat pengaruh Pelaporan Keuangan terhadap Pengendalian Manajemen pada PT. X. Hal ini berarti bahwa pengendalian manajemen dapat berjalan dengan baik jika pelaporan keuangan yang dibuat atau yang di terima dapat menyediakan informasi tentang program dan pusat pertanggungjawaban, dimana proses pengendalian manjemen adalah menilai kinerja pusat pertanggungjawaban. Berdasarkan hasil pengujian signifikan dimana nilai $\mathrm{r}=0.920$ dan nilai cofisien determinan sebesar $84.6 \%$, serta besarnya thitung 12.386. Probabilitas sebesar 0.000 lebih kecil dari 0.05 berarti Ho ditolak yang sesuai dengan rumus hipotesis berarti terdapat pengaruh sangat signifikan Sistem Informasi Akuntansi terhadap Pengendalian Manajemen pada derajat kepercayaan $84.6 \%$

\section{Uji Hipotesis Ke Tiga}

Nilai korelasi antara Sistem Informasi Akutansi (X1) dan Pelaporan Keuangan (X2) secara bersama-sama terhadap Pengendalian Manajemen sebesar 0.850 dengan demikian ada korelasi positif antara variabel artinya bila variabel independen [Sistem Informasi Akutansi (X1) dan Pelaporan Keuangan (X2) ] secara bersama-sama ditingkatkan maka akan diikuti penguatan terhadap variabel Pengendalian Manajemen (Y). Nilai coefiesien determinan [R-square] sebesar $85 \%$ [ $(0.922)^{2} \times 100 \%=85 \%$ ] menunjukkan bahwa variasi peningkatan atau penurunan variabel Pengendalian Manajemen (Y) dapat dijelaskan oleh variabel independen [Sistem Informasi Akutansi (X1) dan Pelaporan Keuangan (X2)] secara bersama-sama sebesar $85 \%$ dengan demikian faktor-faktor lain di luar kedua variabel sebesar $15 \%$ dan hal tersebut tidak dianalisis lebih lanjut. Hasil uji regresi linier berganda memperlihatkan :

Tabel 4.12

Hasil Uji Korelasi

Model Summaryb

\begin{tabular}{|c|c|c|c|c|c|}
\hline Model & $\mathrm{R}$ & R Square & $\begin{array}{c}\text { Adjusted R } \\
\text { Square }\end{array}$ & $\begin{array}{c}\text { Std. Error of } \\
\text { the Estimate }\end{array}$ & $\begin{array}{c}\text { Durbin- } \\
\text { Watson }\end{array}$ \\
\hline 1 & $.922 \mathrm{a}$ & .850 & .839 & 4.40710 & 2.154 \\
\hline
\end{tabular}

a. Predictors: (Constant), Pelaporan Keuangan, Sistem Informasi Akuntansi

b. Dependent Variable: Pegendalian Manajemen 


\begin{tabular}{|c|c|c|c|c|c|c|c|}
\hline \multicolumn{8}{|c|}{$\begin{array}{c}\text { Tabel 4.13 } \\
\text { Hasil Uji Varibel X1, X2 terhadap Y } \\
\text { Coefficients } \\
\end{array}$} \\
\hline \multirow{2}{*}{ Model } & \multicolumn{2}{|c|}{$\begin{array}{l}\text { Unstandardized } \\
\text { Coefficients }\end{array}$} & \multirow{2}{*}{$\begin{array}{c}\text { Standardized } \\
\text { Coefficients } \\
\text { Beta }\end{array}$} & \multirow[b]{2}{*}{$\mathrm{t}$} & \multirow{2}{*}{ Sig. } & \multicolumn{2}{|c|}{$\begin{array}{c}\text { Collinearity } \\
\text { Statistics }\end{array}$} \\
\hline & B & \begin{tabular}{|l} 
Std. \\
Error
\end{tabular} & & & & Tolerance & VIF \\
\hline 1 (Constant) & 8.445 & 4.728 & .079 & 1.786 & .085 & & \\
\hline $\begin{array}{c}\text { Sistem } \\
\text { Informasi } \\
\text { Akuntansi }\end{array}$ & .136 & .147 & & .924 & .364 & .753 & 1.328 \\
\hline $\begin{array}{l}\text { Pelaporan } \\
\text { Keuangan }\end{array}$ & .853 & .083 & .880 & 10.262 & .000 & .753 & 1.328 \\
\hline a & ble: & ndal & Ianajeme & & & & \\
\hline
\end{tabular}

$$
\mathrm{Y}=8.445+0.136 \mathrm{X} 1+0.853 \mathrm{X} 2
$$

Variabel Sistem Informasi Akuntansi dan Pelaporan Keuangan terhadap Pengendalian Manajemen (3)

Dengan demikian nilai constanta sebesar 8.445 merupakan nilai murni variabel Pengendalian Manajemen (Y) tanpa dipengaruhi oleh variabel Sistem Informasi Akutansi (X1) dan Pelaporan Keuangan (X2) secara bersama-sama sedangkan nilai regresi (b1) sebesar 0.136 merupakan nilai kontribusi variabel Sistem Informasi Akutansi (X1) artinya bila variabel Sistem Informasi Akuntansi naik sebesar 1 point maka akan memberikan pengaruh terhadap penguatan terhadap Pengendalian Manajemen sebesar nilai regresi (b1) dan nilai regresi (b2) sebesar 0.853 artinya bila variabel Pelaporan
Keuangan naik maka kencenderungan Pengendalian Manajemen akan naik sebesar nilai regresi (b2).

Hasil uji hipotesis ketiga pengaruh antara [Sistem Informasi Akutansi (X1) dan Pelaporan Keuangan (X2) secara bersama-sama terhadap Pengendalian Manajemen dimana probabilitas untuk $\mathrm{X} 1$ sebesar 0.364 dan $\mathrm{X}_{2}$ sebesar 0.000 dengan demikian pada hipotesis ketiga ternyata Sistem Informasi Akuntansi (X1) tidak berpengaruh secara signifikan terhadap Pengendalian Manajemen (thitung $0.924<$ tabel 2.048) hal ini disebabkan Sistem Informasi Akuntansi telah diadopsi oleh Pelaporan Keuangan karena Sistem Informasi Akuntansi itu sendiri merupakan proses pengolahan data untuk menghasilkan informasi keuangan dalam bentuk laporan keuangan. 


\section{PEMBAHASAN}

Dari hasil uji hipotesis pertama dapat dikatakan bahwa Sistem Informasi Akuntansi berpengaruh secara signifikan terhadap Pengendalian Manajemen dengan tingkat kepercayaan sebesar $26.7 \%$ hal tersebut dipengaruhi oleh ketepatan informasi yang diterima, relevansi SIA terhadap proses pengambilan keputusan oleh manajemen, dan keakuratan informasi yang diterima dalam mewakili kegiatan perusahaan dalam rangka pengendalian manajemen.

Hasil hipotesis kedua Pelaporan Keuangan berpengaruh sangat signifikan terhadap Pengendalian Manajemen dengan tingkat kepercayaan $84.6 \%$, hal tersebut dipengaruhi oleh pelaporan keuangan yang menyajikan antara lain :

1. Penerapan prinsip akuntansi dalam penyusunan laporan keuangan yang berlaku umum dan mudah dipahami.

2. Laporan keuangan yang disajikan dapat memprediksi kelangsungan usaha di masa depan.

3. Laporan keuangan yang disajikan disusun secara sistematis sehingga mudah dimengerti.

Dengan disajikannya laporan keuangan sebagai mana tersebut diatas dapat membantu manajemen dalam pengambilan keputusan yang tepat dan relevan dengan kondisi yang sebenarnya. Dengan kata lain semakin baik pelaporan keuangan yang disampaikan maka pengendalian manajemen akan meningkat dan efektif.

\section{E. KESIMPULAN DAN SARAN Kesimpulan}

Berdasarkan pengujian hipotesis dan pembahasan pada bab sebelumnya maka kesimpulan hasil penelitian ini adalah sebagai berikut :

1. Hipotesis Pertama yang menyatakan bahwa variabel Sistem Informasi Akuntansi (X1) berpengaruh secara signifikan terhadap variabel Pengendalian Manajemen (Y). Hal ini dapat dibuktikan dengan tingkat signifikan variabel Sistem Informasi Akuntansi terhadap variabel Pengendalian Manajemen sebesar 0.003 sedangkan syarat untuk signifikan adalah tingkat signifikan lebih kecil dari 0.005 , dengan demikian dapat diambil kesimpulan bahwa Sistem Informasi Akuntansi berpengaruh secara signifikan terhadap Pengendalian Manajemen, dan besarnya kontribusi X1 kepada $\mathrm{Y}$ dan koefisien determinasinya $\mathrm{R}$ Square adalah sebesar 26,7\%.

2. Hipotesis Kedua menyatakan variabel Pelaporan Keuangan (X2) berpengaruh secara signifikan terhadap variabel Pengendalian Manajemen (Y), Hal ini dapat dibuktikan dengan tingkat signifikan variabel Pelaporan Keuangan terhadap variabel Pengendalian Manajemen sebesar 0.000 sedangkan syarat untuk signifikan adalah tingkat signifikan lebih kecil dari 0.005 , dengan demikian dapat diambil kesimpulan bahwa Pelaporan Keuangan berpengaruh secara signifikan terhadap Pengendalian Manajemen, dan besarnya kontribusi X2 kepada $\mathrm{Y}$ dan koefisien determinasinya R Square adalah sebesar $84,6 \%$. 
3. Hipotesis ketiga yang menyatakan bahwa variabel Sistem Informasi Akuntansi (X1) dan variabel Pelaporan Keuangan (X2) kedua-duanya secara bersama-sama berpengaruh secara signifikan terhadap variabel Pengendalian Manajemen (Y), dari hasil uji regresi linier berganda ternyata yang berpengaruh secara signifikan hanya variabel Pelaporan Keuangan dengan tingkat signifikan sebesar 0.000 sedangkan variabel Sistem Informasi Akuntansi tidak berpengaruh secara signifikan dimana tingkat signifikannya sebesar 0.364, sedangkan syarat untuk signifikan adalah tingkat signifikan lebih kecil dari 0.005 . Dengan demikian dapat disimpulkan bahwa pada saat diuji secara bersama-sama ternyata variabel Sistem Informasi Akuntansi tidak berpengaruh secara signifikan terhadap variabel Pengendalian Manajemen hal ini disebabkan karena variabel Sistem Informasi Akuntansi teradopsi oleh variabel Pelaporan Keuangan.

\section{Saran}

4. Dari hasil uji korelasi terhadap variabel Sistem Informsi Akuntansi diperoleh nilai coefisien determinasinya sebesar $26.7 \%$ dengan demikian bahwa variabel Pengendalian Manajemen dapat dijelaskan oleh variabel Sistem Informasi Akuntansi hanya $26.7 \%$ hal ini disebabkab sistem siformasinya kurang berjalan dengan baik , seperti informasi akuntansi yang di peroleh dari proyek sering terlambat atau kurang lancar sehinga keputusan manajemen yang diambil sering tidak relevan dengan kondisi di lapangan. Untuk itu hendaknya kemampuan/mutu para pegawai ditingkatkan, seperti dengan menetapkan pejabat tertentu (kepala seksi Akuntansi/Kepala Bagian Administrasi dan Keuangan) untuk memberi penataran ataupun pengarahan yang berhubungan dengan administrasi pelaksanaan proyek kepada pegawai yang akan dikirim ke lapangan (proyek); mengikut sertakan pegawai-pegawai dalam pendidikan yang dapat menunjang kemajuan perusahaan serta selalu menyediakan bahan bacaan (majalah, buku-buku) yang berhubungan dengan kegiatan perusahaan dan perekonomian pada umumnya.

5. Informasi Akuntansi perlu dipopulerkan dan di tingkatkan diseluruh divisi bukan hanya dilingkungan divisi-divisi yang berhubungan dengan bidang keuangan saja melalui pemanfaatan jaringan komputer yang terpadu dan melalui kajian yang terus menerus terhadap sistem dan prosedur akuntansi yang digunakan saat ini.

\section{DAFTAR PUSTAKA}

Agus, Erwanto Purwanto (2007), Metode Penelitian Kuantitatif Untuk Administrasi Publik Dan Masalah-Maasalah Sosial Edisi Pertama, Penerbit Gava Media Yogyakarta.

Bagus, Ida Teddy Prianthara. (2010), Sistem Akuntansi Perusahaan Jasa Konstruksi 
Edisi Pertama, Penerbit Graha Ilmu Yogyakarta.

Gondodiyoto, Sanyoto. (2007), Audit Sistem Informasi + Pendekatan Cobit Edisi Revisi, Penerbit Mitra Wacana Media Jakarta.

George. H Bodnar, William S. Hapwood. (2006). Terjemahan Julianto Agung Saputra. Sistem Informasi Akuntansi Edisi 9, Penerbit ANDI Yogyakarta.

Ikatan Akuntansi Indonesia. (2009), Standar Akuntansi Per 1 Juli 2009, Penerbit Salemba Empat Jakarta.

Istimawan, Dipohusodo. (1996), Manajemen Proyek \& Konstruksi Jilid 1, Penerbit Konsius Yogyakarta.

Maulana, Agus (1992), Sistem Pengendalian Manajemen, Penerbit Erlangga Jakarta Martono, Nanang. (2010), Metode Penelitian Kuantitatif: Analisa Isi Dan Analisa

Data Skunder ed 1-1, Penerbit Rajawali Pers Jakarta.

Mulyani, Sri. (2007), Metode Analisis Dan Perancangan Sistem Edisi Pertama, Penerbit Abdi Sistematika Bandung.

Prawironegoro, Darsono. (2009), Akuntansi Manajemen edisi 3, Penerbit Mitra Wacana Media Jakarta.

Susanto, Azhar. (2008) Sistem Informasi Akuntansi: StrukturPengendalian-Risiko-

Pengembangan, Penerbit Lingga Jaya Bandung.

Sumarsan, Thomas. (2011), Sistem Pengendalian Manajemen: Konsep, Aplikasi, dan Pengukuran Kinerja, Penerbit Indeks Jakarta. 